\title{
INDOOR THERMAL ENVIRONMENT OF URBAN RESIDENTIAL BUILDINGS IN LHASA, CHINA
}

\author{
WANG, Q. - ZHAO, J. Y. \\ School of Architecture, Chang'an University \\ No. 75 Chang'an Middle Road, 710061 Xi'an, China \\ (phone: +86-29-8233-7241; fax: +86-29-8220-2729) \\ *Corresponding author \\ e-mail: zjyqtt@163.com; phone: +86-186-9182-0234; fax:+86-29-8220-2729 \\ (Received 23 $3^{\text {rd }}$ Feb 2019; accepted $3^{\text {rd }}$ May 2019)
}

\begin{abstract}
In Lhasa area, the solar radiation intensity is relatively high, so in order to satisfy the indoor natural lighting quality, it is easy to cause overheating in the south-facing room and non-uniform heat in the north-facing room with lower room temperature. In this paper, Dest-h software is used to simulate and study the base temperature and average energy consumption of non-heating residential buildings under different window-wall ratio and partition wall conditions, trying to find out the structural measures and design methods to improve the indoor thermal uniformity.
\end{abstract}

Keywords: solar radiation intensity, non-uniformity, Dest-h, base temperature, building energy consumption

\section{Introduction}

As a cold area, Lhasa needs heating in winter according to the Code of Thermal Design of Civil Buildings in China. But heating is expensive because fuel and coal are imported from other areas. However, thanks to the strong solar radiation, the annual sunshine time of more than $3,000 \mathrm{~h}$, and the annual total solar radiation of $7,000 \mathrm{MJ} / \mathrm{m}^{2}$ (Xiao, 2010), Lhasa region has unique solar energy resources. Through literature review (Zhang and Liu, 2008; Li and Liu, 2017; Liu, 2017; Kang, 2012; Li, 2017) and field review in 2016-2017, it was found that the flat roof buildings sitting north and south are adopted most commonly in this area, maximizing the use of opening area of southfacing glass window or passive energy-saving technology with additional sunshine, so as to obtain more solar radiation heat, thereby increasing the indoor temperature of the room, and ultimately reducing the heating load demand of the building. Nonetheless, the contradiction between excessive heating area and strong solar radiation resources makes indoor thermal non-uniformity the most significant thermal comfort problem of residential buildings in this area. For example, in winter, the south-facing room is overheated during the day, residents need to open windows, and the north-facing room has a lower temperature all day, residents are unwilling to stay in it.

Based on the field test and simulation analysis of residential buildings in cities and towns in Tibet Plateau, Liu et al. (2011) put forward the basic theory and calculation method of low-energy building design suitable for the natural and climatic conditions of Tibet Plateau. In view of the abundant solar energy resources in this area, Yang et al. (2010) put forward a heating mode that is mainly passive solar heating, supplemented by active heating and other heating modes, and combined it with passive and active heating, in order to improve the indoor thermal environment quality and reduce building energy consumption. Liu et al. (2008) tested the indoor and outdoor temperature of traditional houses in Lhasa area, and concluded that increasing the area of south-to- 
outdoor windows does not reduce the indoor minimum temperature, but can also improve the indoor average temperature and maximum temperature. Wang et al. (2012) tested and compared the indoor thermal environment of two residential buildings in Tibet using traditional building materials and modern building materials. It was concluded that the thermal insulation performance of traditional building materials in eastern Tibet was better than that of modern building materials. Wang (2018) divided the typical rural buildings in Tibet into space zoning modes, determined the structural parameters and thermal performance of the local typical building envelopes, and simulated and analysed the zoning modes. Domestic papers building thermal environment research in Tibet focuses, mainly on rural building envelope materials or indoor thermal environment energy-saving design, but there are few studies on indoor thermal heterogeneity, especially in urban residential buildings.

Aiming at the problem of indoor thermal non-uniformity in Lhasa area, the dynamic simulation of energy consumption of typical buildings in south and north rooms was carried out in this paper, according to the requirement of $65 \%$ energy saving in Lhasa area by means of Dest-h software simulation analysis, and the structural measures and design methods to improve the indoor thermal non-uniformity were explored in order to further improve the indoor thermal environment quality of buildings there.

\section{Methodology}

\section{Climate parameters}

In order to avoid the influence of weather instability on the accuracy of the calculation results, the typical meteorological year data (TMY) was used as the input condition, which is the hourly meteorological data of DeST software, and the number of air exchange is 0.5 times/h (Tianjin Eco-city Green Building Research Institute, Tsinghua University Building Energy Research Center, 2009). Room heat disturbance is determined by its use function. Indoor per capita calorific value was set at $53 \mathrm{~W}$; lighting load was set at $60 \mathrm{~W}$ according to gross index input; the equipment load was set at $12.7 \mathrm{~W} / \mathrm{m}^{2}$ according to the average index input.

The slab buildings with two families sharing one staircase are the most representative residential building model in Lhasa. Usually, the buildings in this area are oriented to the south, with 6 stories and $3 \mathrm{~m}$ high. The plan is shown in Figure 1.

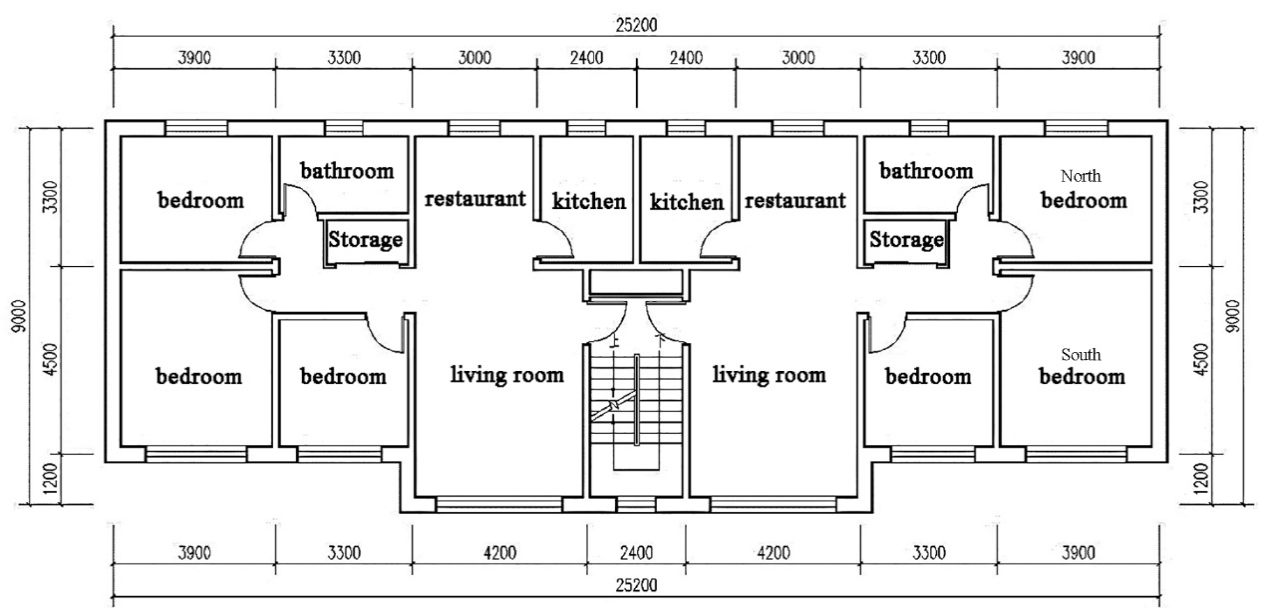

Figure 1. Simulated model plan 


\section{Building envelope parameters}

The parameters of roof, exterior wall, interior wall, ground, floor, exterior window and exterior door are set at the limit value prescribed by the code (DBJ540001-2016, 2016). The thermal parameters of materials and components are selected from the Code for Thermal Design of Civil Buildings, as shown in Table 1.

Table 1. Thermal parameters of building envelope

\begin{tabular}{c|c|c}
\hline Name of envelops & Materials of envelops & $\begin{array}{c}\text { Heat transfer coefficient K } \\
\mathbf{W} /\left(\mathbf{m}^{2} \cdot \mathbf{K}\right)\end{array}$ \\
\hline Roof & $\begin{array}{c}\text { 20 thick lime mortar }+50 \text { thick polyurethane } \\
\text { insulation layer }+20 \text { thick cement mortar }+100 \\
\text { thick reinforced concrete slab }+20 \text { thick cement } \\
\text { mortar }\end{array}$ & 0.42 \\
\hline Exterior wall & $\begin{array}{c}20 \text { thick lime mortar }+40 \text { thick extruded } \\
\text { polystyrene board }+370 \text { thick lime sand brick } \\
\text { wall }+20 \text { thick cement mortar }\end{array}$ & 0.53 \\
\hline Interior wall & $\begin{array}{c}20 \text { thick cement mortar }+240 \text { thick cement-sand } \\
\text { brick wall }+20 \text { thick cement mortar }\end{array}$ & 2.0 \\
\hline Ground & Concrete floor & 2.9 \\
\hline Floor & $\begin{array}{c}20 \text { thick cement mortar }+60 \text { thick lightweight } \\
\text { aggregate concrete }+100 \text { thick reinforced } \\
\text { concrete slab }+20 \text { thick cement Mortar }\end{array}$ & 4.8 \\
\hline Exterior window & $6+12+6$ double glazed window & 2.8 \\
\hline Exterior door & Solid wood door & 2.0 \\
\hline
\end{tabular}

\section{Results}

\section{Window-wall ratio}

The window-wall ratio is a key index affecting indoor thermal environment. It is stipulated in the Design Standard for Energy Efficiency of Residential Buildings in Severe Cold and Cold Zones that the window-wall ratio of residential buildings in Cold Area A is not more than 0.5 (JGJ 26-2010, 2010). However, there is no limit value of window-wall ratio in the Standard for Energy-saving Design of Civil Buildings in Tibet Autonomous Region. But Lhasa is a cold area with strong solar radiation. The larger the size of the window opening, the greater the heat loss in the room. For the north room, the window size only needs to meet the functional lighting requirements of the room. Therefore, the northward window-wall ratio is set to 0.12 . For the south room, it is necessary to maximize the solar radiation heat, but also to prevent indoor overheating. As a result, the south-facing window-wall ratio range is $0.3-0.8$.

With the same thickness of partition wall and different window-wall ratios, the dynamic simulation of energy consumption of typical buildings in south and north rooms was carried out by using Dest-h software. Results are shown in Figure 2, when the window-wall ratio in residential buildings is too large, that is, above 0.6 , the average building energy consumption value has dropped to $0 \mathrm{w} / \mathrm{m}^{2}$, the base temperature of the south room has reached $26.37^{\circ} \mathrm{C}$, and that of the north room is $19.96{ }^{\circ} \mathrm{C}$, and the temperature difference between the two rooms is $6.41^{\circ} \mathrm{C}$. As shown in Figure 3, the base temperatures of the south room and north room increases with the increase of the south window-wall ratio. With the increase of the south window-wall ratio, the 
temperature fluctuation of the south room increases from 1.52 to $3.45^{\circ} \mathrm{C}$, and the temperature fluctuation of the north room increases from 0.8 to $1{ }^{\circ} \mathrm{C}$. The temperature difference between the south room and north room increases from 4.31 to $7.28{ }^{\circ} \mathrm{C}$, and the fluctuation also increases significantly. If only the south window is used to obtain the solar radiation, when the window-wall ratio is 0.4 and above, the average temperature of the room is above $16^{\circ} \mathrm{C}$, which basically meets the requirements of indoor thermal environment.

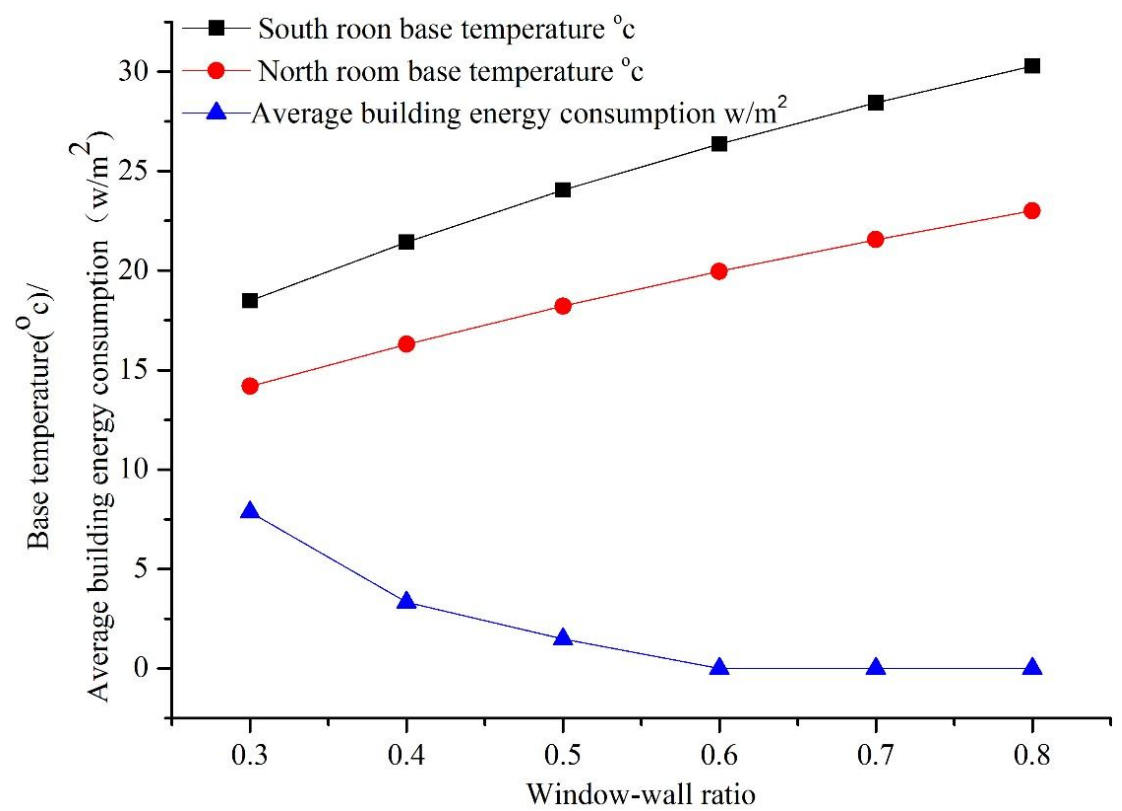

Figure 2. The base temperature and average building energy consumption of south room and north room on the coldest day in Lhasa area with different window-wall ratios

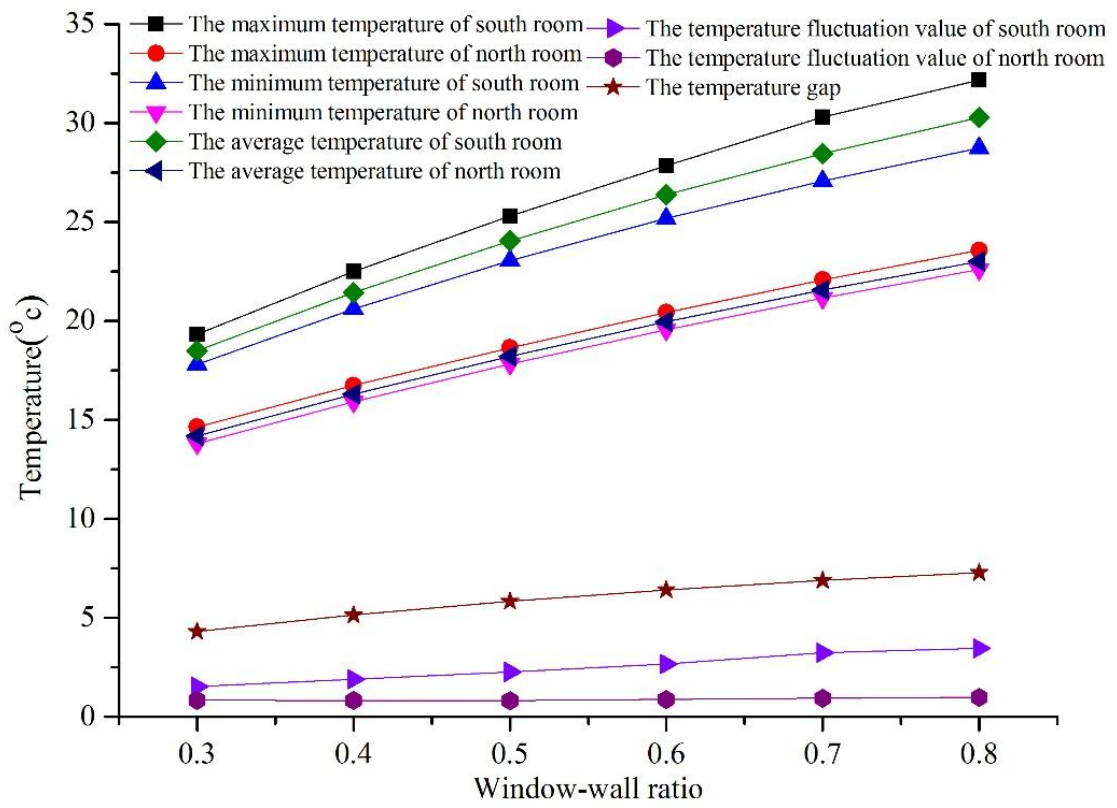

Figure 3. The maximum, minimum, average temperature and temperature difference of south room and north room on the coldest day without heating $\left({ }^{\circ} \mathrm{C}\right)$ 


\section{Partition wall}

Under different heat transfer coefficients, the base temperature of rooms facing south and north of residential buildings in Lhasa area was simulated and analyzed. The values of different heat transfer coefficients $\mathrm{K}$ and the corresponding partition construction methods are shown in Table 2.

Table 2. Values of different heat transfer coefficients $K$ and their corresponding partition construction practices

\begin{tabular}{c|c|c}
\hline \multirow{2}{*}{ Conditions } & $\begin{array}{c}\text { Heat transfer coefficient } \\
\mathbf{K}\left[\mathbf{W} /\left(\mathbf{m}^{\mathbf{2}} \cdot \mathbf{K}\right)\right]\end{array}$ & Recommended practices of partition wall construction \\
\cline { 1 - 3 } Case1 & 0.7 & 200 thick aerated concrete block wall $(0.723)$ \\
\hline Case2 & \multirow{2}{*}{ 1.2 } & 100 thick aerated concrete block wall $(1.207)$ \\
\cline { 1 - 2 } Case3 & 1.6 & 370 thick porous brick wall $(1.248)$ \\
\hline Case4 & 2.0 & 240 thick porous brick wall $(1.624)$ \\
\hline Case5 & 2.3 & 370 thick lime sand brick wall $(1.641)$ \\
\hline Case6 & 2.6 & 240 thick lime sand brick wall $(2.036)$ \\
\hline Case7 & 3.2 & 120 thick porous brick wall $(2.251)$ \\
\hline Case8 & 6.3 & 120 thick lime sand brick wall $(2.618)$ \\
\hline Case9 & Case10 & 50 thick plasterboard partition $(3.23)$ \\
\hline
\end{tabular}

Under the same window-wall area ratio, different thickness of partitions and construction methods, the hourly room temperature comparison curves of south and north-facing rooms in winter solstice are shown in Figures 4 and 5. Even in the case of glass partitioning, although the thermal non-uniformity of rooms in the south and north directions decreases, there is still a temperature difference of $5.01{ }^{\circ} \mathrm{C}$. The results show that after the passive energy-saving technology is maximized, the large temperature difference between the south and north-facing rooms still exists. Therefore, the main method to solve the problem of indoor thermal non-uniformity is how to make rational use of the south-facing heat collection area to store or transfer heat to the north-facing room.

\section{Discussion}

If only the south window is used to obtain the solar radiant, when the east and the west window-wall ratios are 0 , the north window-wall ratios is 0.12 , the south windowwall ratio is greater than or equal to 0.4 . On the coldest day, the average temperature of the south and the north rooms is above $16^{\circ} \mathrm{C}$, which basically meets the requirements of indoor thermal environment. If the south window-wall ratio is greater than 0.4 , the fluctuation value of base temperature in south room is greater than that in north room, and the fluctuation value of base temperature in north room is basically unchanged, which indicates that the heat from the south room is difficult to transfer to the north room. Therefore, it is considered to adopt a solar building form to solve indoor thermal non-uniformity when the south in south direction is greater than 0.4 . 


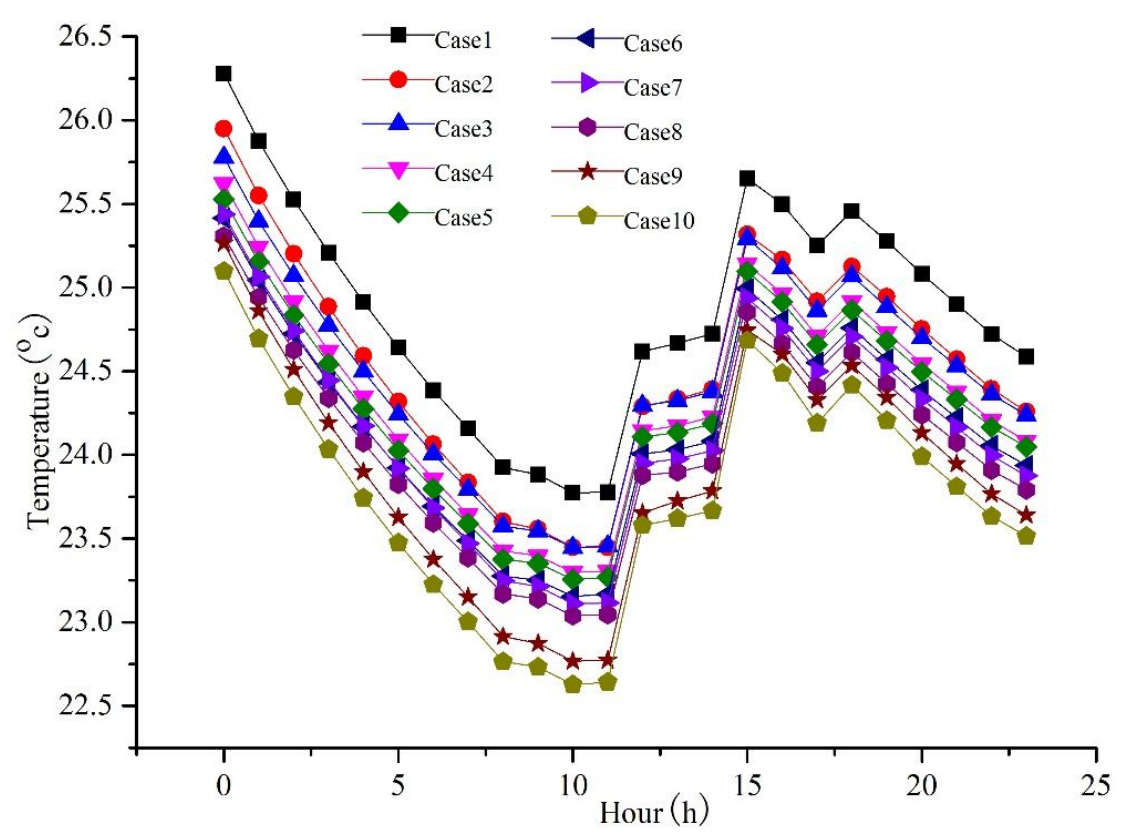

Figure 4. Comparison of room temperature in south room under different partition conditions on winter solstice

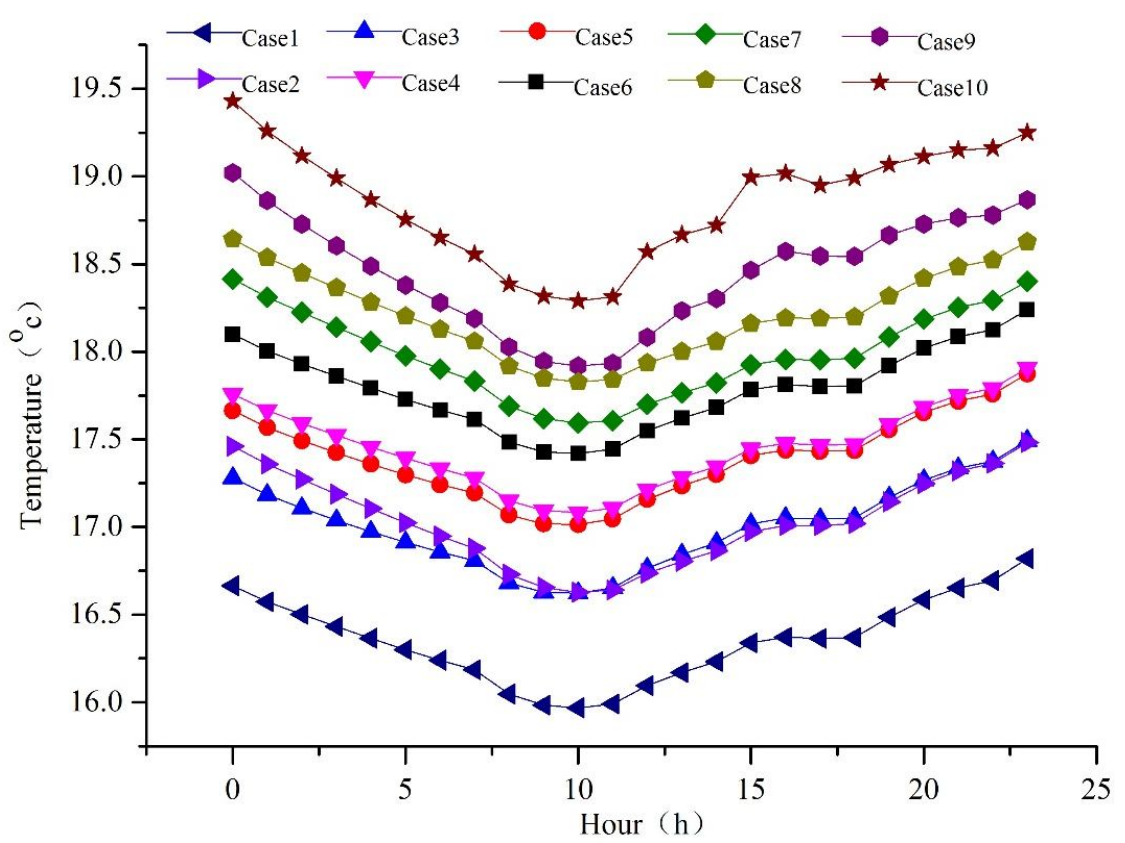

Figure 5. Comparison of room temperature in north room under different partition conditions on winter solstice

At present, the research focus of solar energy utilization in Lhasa area is on improving the efficiency of heat collection, which should be transferred to utilizing heat transfer to solve the non-uniformity of indoor temperature field. However, in the organic integration and utilization of building materials, building structures, building 
equipment and intelligent control methods, it still has the characteristics of simplification and one-sidedness. How to utilize the seasonality, randomness, periodicity and controllability of solar energy in different seasons, different periods and different heating areas to obtain the reasonable heat control, storage and use management of solar energy in time-sharing, zoning and seasons is an effective means to reduce energy consumption, improve indoor thermal comfort and solve the problem of non-uniformity of indoor temperature field.

In terms of installation mode, flat-plate solar collectors are mostly installed in fixed way in solar energy building, and wall-mounted type is adopted in order to ensure solar energy collection area in installation position. However, the former cannot adjust the angle of solar panels according to the change of all-day solar elevation angle, which leads to low efficiency of solar energy acquisition; the latter affects the facade design of buildings on the one hand. The latter on the one hand affects the design of building exterior facade, on the other hand has some potential safety hazards because it hangs directly on the wall surface. Therefore, the integrated design method of solar building with window solar energy system as heat storage component can be considered. At the same time, glass partition or light partition wall with large heat transfer coefficient should be adopted as indoor partition wall as far as possible.

\section{Conclusions}

In this paper, the indoor thermal environment and energy consumption of residential buildings in Lhasa under different window-to-wall ratios and partition conditions were simulated and analyzed. The results show that the indoor thermal environment of residential buildings in Lhasa still exhibits thermal non-uniformity under the condition of maximizing the use of passive energy-saving technology. When the east and the west window-wall ratios are 0 , the north window-wall ratios is 0.12 , the south window-wall ratio is greater than or equal to 0.4 , glass partition or light partition wall with large heat transfer coefficient should be adopted as indoor partition wall as far as possible. On this basis, it is necessary to build window solar energy storage and energy-using equipment in combination with local climate, so that thermal energy can be transferred from south to north-facing rooms, reduce or avoid indoor discomfort, and reduce energy consumption.

Acknowledgements. This work was financially supported by National Key Research Project of China (Project No.: 2016YFC0700400); Fundamental Research Funds for the Central Universities of China (Project No.: 310841172101$)$.

\section{REFERENCES}

[1] DBJ540001-2016 (2016): Tibet Autonomous Region Energy Efficiency Design Standard for Civil Buildings. - Tibet People's Publishing House, Tibet.

[2] JGJ 26-2010 (2010): Energy-saving design standards for residential buildings in severe cold and cold regions. - China Building Industry Press, Beijing.

[3] Kang, H. T. (2012): Study on design of low energy consumption residential buildings in Plateau alpine region. - Xi' an University of Architecture and Technology, Xi'an. 
[4] Li, E. (2017): Analyses of influence of residential building space organization on heating energy consumption in Lhasa. - Journal of Southeast University (English Edition) 33(4): 457-465.

[5] Li, E., Liu, J. P. (2017): Influence of the buffer-space design on winter heating energy consumption in Lhasa. - Journal of Civil, Architectural \& Environmental Engineering 39(04): 40-47.

[6] Liu, J. P., Yang, L., Liu, Y. F., Tian, G. M. (2011): Key technological research and application of low energy consumption building design in Tibet. - China Engineering Science 13(10): 40-46.

[7] Liu, L. (2017): Study on Energy-saving Reconstruction Scheme of Residential Building Envelope in Lhasa Area. - Xi Hua University, Chengdu.

[8] Liu, Y. F., Liu, J. P., Yang, L., Li. J. (2008): Measuring study of passive solar house for traditional dwelling building in LhaSa area. - Solar Energy 4: 391-394.

[9] Tianjin Eco-City Green Building Research Institute, Tsinghua University Building Energy Research Center (2009): Building Energy Simulation and Operating Tutorial of eQUEST \& DeST. - China Building Industry Press, Beijing.

[10] Wang, P. Q., Leng, Y. H., Xu, G. T. (2012): Analysis on thermal environment current situation of residential buildings in the south-eastern of Tibet. - Architecture Science 28(03): 65-68.

[11] Wang, W. K. (2018): Study on Thermal Design and Energy Saving Structure of Indoor Partition Solar Heating Building. - Xi'an University of Technology, Xi'an.

[12] Xiao, W. (2010): Study on the Direct-Gain Solar Heating in Remote Southwest Tibet. Tsinghua University, Beijing.

[13] Yang, L., Zhu, X. R., Liu, Y. F., Liu, J. P. (2010): Review of design standard for energy efficiency of residential buildings in Tibet Autonomous Region. - HVAC 40(09): 51-54.

[14] Zhang, Y. Z., Liu, J. P. (2008): Current state and the trend of development of residential building in Lhasa. - Journal of Architecture 11: 33-35. 